\title{
Reflections on the SARS-Covid-2 pandemic after one year: predictable, preventable but inevitable: an ecologist's perspective
}

\author{
Jeffrey A. HARVEY \\ Department of Terrestrial Ecology, The Netherlands \\ VU University Amsterdam, The Netherlands \\ Received: 02.03.2021, Revised: 19.03.2021, Accepted: 19.03.2021 \\ doi: http://dx.doi.org/10.29015/cerem.912
}

\begin{abstract}
:
Aim: The major aim of the current essay is to argue that neoliberal capitalism, by virtue of its core tenets, has significantly increased the risk of disease outbreaks like SARS-Covid-2.

Conclusion/Finding: The dominant socio-political-economic system across the industrialized world is neoliberal capitalism that focuses on economic growth and profit maximization. These are obtained in part through the weakening or elimination of environmental regulations. Although neoliberalism has brought benefits to some, it has exacerbated social and economic divisions within and between countries. More importantly, it is undeniably responsible for increasing the rate of environmental destruction, especially in developing countries in the south, which are rich is resources and raw materials coveted by multinational corporations based in the western developed countries. The loss and/or fragmentation of ecosystems is also bringing people into closer contact with many species that were once largely insulated from human communities, such as bats, that harbor harmful viruses with the potential to affect people through zoonotic spill-over via another wild or domesticated species.
\end{abstract}

Originality/Value of Article: Because it eschews the precautionary principle, neoliberal capitalism is uniquely ill-equipped to prepare for potential calamities like pathogenic outbreaks and, more worryingly, climate change. This makes it obsolete in the Anthropocene. We need to seriously work towards making structural changes in the socio-political landscape in ways that reduce the damage we are doing and also strive to create social justice across the world. This is imperative if we are to create a sustainable future and to protect much of the living world from destruction.

Keywords: climate change; environmental destruction; extinction; habitat; neoliberal capitalism; profit

JEL: F64, P10, Q54

Correspondence address: Jeffrey A. Harvey, Department of Terrestrial Ecology, Netherlands Institute of Ecology, Droevendaalsesteeg 10, 6700 AB Wageningen, The Netherlands, VU University Amsterdam, Department of Ecological Sciences, Section Animal Ecology, De Boelelaan 1085, 1081 HV Amsterdam, The Netherlands E-mail: J.Harvey@nioo.knaw.nl 


\section{Introduction}

A rapidly increasing human population, combined with the advent and spread of globalization, has led to increased and unprecedented pressures on the environment (Ehrenfeld 2005). Humans are fragmenting and destroying vast tracts of natural ecosystems across the biosphere, actions that not only are wreaking havoc on biodiversity, food webs and ecosystem functions, but at the same time are bringing increasing numbers of people into much closer contact with species that were once insulated from human communities (Daszak et al. 2001). Nature is represented by a veritable labyrinthine network of ecological complexity that is inexorably connected through a chain of cause-and-effect relationships (Quammen 2012; Aronsson, Holm 2020). Most importantly, natural ecosystems into which humans are increasingly making incursions are literally brimming with pathogens, many of which are viruses that have to potential to infect us directly (like smallpox and polio), or via zoonotic transfer, via another species (i.e. Ebola, Hantavirus, Hendra virus, Nipah virus, MERS, SARS-Covid-1, SARS-Covid-2). Some of the most infectious and dangerous viruses that have historically led to deaths of millions of people, and which continue to pose a massive threat to humanity today, such as chicken pox, measles, and various strains of influenza are all zoonoses that were passed onto humans from a secondary host via a primary host (Wimalawansa 2020). Zoonotic spill-overs occur when secondary hosts - wild animals such as civets or pangolins, or domesticated animals such as pigs, horses or chickens - are infected by a primary host, such as bats, which are known to possess potent immune responses that allow them to harbour an array of pathogens (Plowright et al. 2015; Ye at al. 2020).

Over the past year, the entire world has been rocked by the largest human viral infection in over a century. SARS-Covid-2 was first detected in the vicinity of an animal market in Wuhan, China, in December, 2019, when several people (not all had visited the market) exhibited symptoms of a respiratory infection ( $\mathrm{Xu}$ et al. 2020). Thereafter, the virus began spreading from China to other parts of the world on commercial airlines (Hoehl et al. 2020). As of this writing (early March, 2021), one year after being formally recognized by the World Health Organization (WHO) as a pandemic (Cucinotta, Vanelli 2020), SARS-Covid-2 has infected some 115 
million people and claimed over 2.5 million lives in almost every corner of the globe (https://www.worldometers.info/coronavirus/), although the unofficial infection and death tolls are undoubtedly much higher. Furthermore, the economic costs of the virus, via a massive slowdown in economic output, are staggering, amounting to trillions of dollars by now, with a potential final price tag of as much as 35.3 dollars by 2025 (https://www.thenationalnews.com/business/economy/covid-19-may-costglobal-economy-35-3-trillion-by-2025-1.1069246). There is some light at the end of the tunnel via an unprecedented scientific response in developing multiple vaccines in record time (Kim et al. 2020). Despite that, the shadow of SARS-Covid-2 has been cast on humanity for years, perhaps decades, to come.

\section{The natural (ecological) origin of SARS-Covid 2 is indisputable}

Despite a proliferation of nonsensical and often quite bewildering conspiracy theories as to the origin of SARS-Covid-2 (Ahmed et al. 2020; Allington et al. 2020; O'Connor et al. 2020), there is little doubt by now that it originated in bats (probably horseshoe bats) and then somehow infected another species before infecting man (Lau et al. 2020; Zhou et al. 2020). The most likely conduit for this infection appears to be pangolins that are native to SE Asia and which are kept in large numbers in animal markets (Lopes et al. 2020; Zhang et al. 2020). SARS-Covid-1, which killed several hundred people and had a higher infection fatality rate than SARS-Covid 2, infected humans via civets that in turn had been harboured by bats (Childs et al. 2007). Although the precise geographical and zoological origins of the coronavirus are still being heavily debated, there is little doubt that it is a completely natural pathogen that originated in wild populations of a native species, most likely bats, and that it somehow infected another species where the viral genome was amplified before infecting man. Attempts to explain the global SARS-Covid 2 outbreak as an 'anomaly', or because the virus was either deliberately or accidentally released from a laboratory, are profoundly wrong and dangerous. The fact is not that the global pandemic occurred, but that it has taken as long for it to happen (after the Spanish flu outbreak of 1918-19), given the combined effects of the current socio-political system and the human onslaught on nature (Haas 2020). Indeed, everything around 
the SARS-Covid-2 pandemic that has transpired was both predictable and preventable.

\section{The SARS-Covid 2 pandemic was predictable, preventable but inevitable}

One of the most astonishing aspects of the SARS-Covid-2 outbreak spread and subsequent establishment in 219 countries and territories around the world is how much pundits in the media and politicians have feigned shock and disbelief at the turn of events (Sternfeld 2020; Volpert et al. 2020). If anything, as stipulated above, an outbreak of a major viral infection was inevitable, given the numerous ways that humans interact with nature, exploit both wild and domesticated animals, and embrace a socio-political economic system that is singularly unprepared to deal with potential calamities. Neoliberal capitalism is perhaps the worst system in human history when it comes to preparedness for immediate threats like a viral outbreak, and especially slower, more existential threats like climate change.

Neoliberal capitalism, which is neither new nor liberal, replaced a more egalitarian form of capitalism in the late 1970s, coinciding with the administrations of Prime Minister Margaret Thatcher in the United Kingdom and President Ronald Reagan in the United States (Jones 2014). A recent history of neoliberalism is described by Peters (2012) and Kotz (2015). The core tenets of neoliberal capitalism include deregulation, the elimination or weakening of trade-unions, reduced taxation, especially for the corporate sectors and ruling elites, and adoption of 'trickle-down' economics in the hope that a concentration in wealth will lead to increased philanthropy (Hickel 2018). Neoliberal economics is closely tied with neoclassical economic theory, which cites human ingenuity, efficiency and unlimited substitutability among its core tenets (Czech 2000). Economic growth is a priority under the auspices of neoclassical economics, and is closely affiliated with the underlying motivation of profit maximisation that undergirds neoclassical economics.

There is little doubt that neoliberal capitalism is uniquely ill-equipped to cope with the emergence of pandemics and the burgeoning threats of global environmental destruction and climate change that characterize the Anthropocene. 
Under neoliberalism, most corporations focus on profit maximization (Chomsky 1999; Duménil, Levy 2002; Monbiot 2016) while espousing slogans like 'corporate social responsibility' that are often little more than a public relations exercise (L'Etang 1994; Hanlon, Fleming 2009). The focus on profit places enormous constraints on the ability of governments and institutions to apply laws and regulations that protect society and the environment from corporate excess. The regulation of risk that was once well inculcated onto our political landscape via the precautionary principle has been increasingly downplayed or ignored as neoliberal capitalism has become more deeply rooted. The precautionary principle broadly states that it is better to be safe than sorry; in other words, a comprehensive scientific cause-and-effect relationship understanding is not necessary if an activity poses clear risks to human and environmental health (Foster et al. 2000; Kriebel et al. 2001). Part of the problem in implementing the precautionary principle is that its definition has sometimes been accused of being too vague and ambiguous, and that, if wrongly implemented, it will stifle growth and progress (Sandin et al. 2002).

Given the iron-like grip that the 'Washington Consensus' (neoliberal doctrine) has over most of the industrialized world, is therefore unsurprising that the precautionary principle was virtually ignored as SARS-Covid-2 began to spread across the globe in January of 2020. By the end of that month, the WHO was issuing dire warnings about the potential for the virus to become a pandemic, although the formal declaration was not made until March 11, 2020 (Cucinotta, Vanelli 2020). However, by February of 2020, SARS-Covid-19 was detected in every continent (Vlachopoulos 2020). At that time epidemiologists were already issuing stern warnings that their governments needed to respond instantaneously and decisively in ways to contain and suffocate the virus, preventing it from reaching a 'critical mass' that would permit it to spread. Indeed, they had been warning of an imminent pandemic for many years before that (Quammen 2012; Henig 2020), but their pleas have repeatedly fallen on deaf ears.

In hindsight, is relatively easy to understand why governments did not act immediately to prevent the emergence of the pandemic. Beholden to the frontloaded neoliberal doctrine, politicians were afraid of being accused of 'crying wolf' if they implemented draconian measures such as lock downs, curfews, and closed 
borders, before the virus had taken hold (Platje et al. 2020). To be fair, their hands were effectively tied behind their backs by the corporate sector: if they did take drastic precautionary measures to safeguard their populations, and the virus fizzled out, then they were committing 'political suicide', because it could be argued that the virus would have disappeared anyway. Why impose massive risks on economies for a perceived threat? After all, wasn't this the case with SARS-Covid-1 sixteen years earlier? It was a case of 'damned if you do, damned if you don't'. Certainly, some measures were taken to control the outbreak of SARS-Covid-1, but nothing that significantly interfered with the vagaries of the hair-trigger neoliberal economies of the world. So, instead of responding proactively to a clearly growing threat posed by SARS-Covid-2, most western governments effectively sat on their hands and waited... and waited... and waited... until it was too late to contain the virus. By then, Pandora's box has effectively been opened; governments have been playing catch-up and reacting to viral waves ever since.

The 'sit and wait' strategy has, in my opinion, thus been an epic failure that has exacted an enormous economic and human toll. The toll has fallen heavily on poorly-paid workers employed by small firms that simply cannot keep them on the payroll, or else by large corporations that do not maintain 'contingency funds' in the case of an emergency. Instead, profits are ploughed into investor's portfolios. Large corporations in the travel sector, such as airlines, were among the first to seek government support when the pandemic led to lockdowns, stricter border controls and reduced business (Abate et al. 2020; de Rugy, Leff 2020). Ironically, as the pandemic has been tearing through most nations across the world, the number of billionaires also continued to increase (Collins et al. 2020; Kelly 2020). Among the clear 'winners' from the pandemic in terms of profit are the big pharmaceutical companies; for them, it can arguably be said that viral outbreaks are 'big business' because they will hold patent rights over the vaccines they develop. However, the longer-term profitability of SARS-Covid-2 vaccines are open to conjecture (Hooker, Palumbo 2020). Nevertheless, a deep concern is that poor nations that cannot afford vaccines will be unable to vaccinate much of the populations, further illustrating the gaping moral and ethical holes in neoliberal capitalism (Berthelsen 2020). 
What has exacerbated the harmful effects of 'reactive', as opposed to 'proactive' government responses to SARS-Covid-2 outbreaks and waves, has been the refusal of some individuals to co-operate with measures, such as lock downs, curfews, mask-wearing and social distancing, that were implemented to suppress or contain viral spread and to prevent health care systems from buckling (Leung et al. 2020). This is another by-product of a generation in wealthy countries that has been weaned on 4 decades of the neoliberal-inculcated doctrine of 'unlimited freedom'. In other words, a small but significant minority of people in industrialized nations resent any measures that suppress their 'individual rights'. This mutant form of hedonistic devotion to self-interest over the broader interests of society is, some scholars believe, a clear by-product of neoliberal indoctrination (Amable 2011; McGuigan 2014; Giroux 2015). With the looming effects of climate change representing a much more serious threat to humanity than the current pandemic, the two-pronged effects of neoliberal capitalism: front-loaded economics that eschew the precautionary principle, and prioritization of individual rights over the welfare of society, does not bode well for the future.

Finally, must also acknowledge that neoliberalism has created a hugely divided world, where technologies are hoarded by the wealthy nations and the costs of pursuing unlimited economic growth are disproportionately paid for by the poor in the south (Athansiou 1996; Hickel 2017, 2018). Essentially, neoliberalism has led to the dissolution of borders and increased the spread of globalization which has allowed corporations to flee regulations in the wealthy countries to set up veritable sweat-shops in poor countries that are desperate for foreign investment (Bond 2006; Walker 2008; Donnelly 2019). Once established there, they can exploit cheap labour, virtually non-existent public health and environmental laws and thus plunder capital which is expropriated and shipped back to western markets. Ironically, political processes like 'free-trade' (which is an illusion) and globalization are embedded in neoliberal doctrine, but under the SARS-Covid-2 pandemic they conflict with public health and attempts to control the viral spread. In other words, border controls and strict quarantining that are necessary to contain the spread of the virus are the kinds of responses that are alien to neoliberal doctrine. 


\section{Concluding remarks}

I have argued that the ability of SARS-Covid-2 to become a global pandemic was both predictable and preventable. Human biomass now exceeds all combined wild mammalian biomass by as much as ten times - with most of the remainder being made up of domesticated livestock (sheep, cattle, pigs, goats etc.) that is grown for human consumption (Bar-on et al. 2018). Moreover, we are entering the initial stages of a major extinction event - the sixth in the Earth's history - and the first that is generated by one of the planet's involved inhabitants (us). The combined effects of ploughing, paving, damming, dredging, slashing-and-burning, logging, mining, hyper-eutrophication or draining of wetlands, biological homogenisation via invasive species, dousing the planet in synthetic pesticides, and various other forms of pollution, including climate change, are placing stresses on nature and biodiversity that are unprecedented in tens of millions of years and perhaps longer (Dirzo et al. 2014). These drivers rarely work independently but are inexorably connected and synergized (Brook et al. 2008). Most importantly, as humans continue our assault across the biosphere, cutting our way deep into the heart of once-inaccessible ecosystems (especially in tropical biomes), we are blindly exposing ourselves to a potential array of novel pathogens. We are fortunate in a way that SARS-Covid-2 is relatively benign, with data from 139 countries reporting an infection fatality rate of approximately $1 \%$ (Grewelle et al. 2020). The next virus to become a pandemic may well turn out to rival the Spanish flu in terms of human mortality.

The question is, given that SARS-Covid-2 was both predictable and preventable, why do I believe that it was inevitable? This harkens back to the neoliberal political system which is entrenched across the industrialized world. Given the impotence that governments across the world displayed in response to concerted pressure for the corporate lobby to retain a 'business-as-usual' ethos until the horse had metaphorically bolted from the barn, is there any indication that we will be better prepared for the next one? My prognosis, writing as a population ecologist whose research involves the effects of climate extremes on biotic interactions, is not an optimistic one. Some forty years ago, leading atmospheric scientists and climate 
scientists began raising the alarm about anthropogenic climate change (Rich 2019). Since that time, apart from relatively pedantic measures, the human response has been pitiful. The climate crisis by now is seen as the gravest threat to mid-term human survival, and yet, despite increasing urgency, much of the developed world continues to procrastinate and drag its feet, with wealthy nations failing to meet emissions targets. Although the vast majority of scientists forcefully argue the need to keep the global surface temperature rise under 2 degrees $\mathrm{C}$ over the coming decades (Rojelj et al. 2016), it appears that, even under conditions stipulated in the Paris Agreement (2015), that we will not keep surface temperatures under 3 degrees C (Kerr 2004). This will push our ecological life-support systems to the brink, and perhaps beyond.

Bearing these facts in mind, and given the planetary addiction to a fossil-fuel driven economy, is it really surprising that we are collectively unable to respond to the emerging climate catastrophe? Moreover, if we remain paralyzed in the face of a clearly imminent threat, such as SARS-Covid-2, then how will we respond to the much more serious threat posed by climate change? Indeed, will we even be prepared for the next pandemic, which is probably inevitable in the next several decades? An old axiom goes that, 'those who do not learn from history, are doomed to repeat it', and this most certainly applies with the SARS-Covid-2 pandemic (Thompson 2020). With climate change, we may very well get only one turn 'at bat'. There will be no opportunity to repeat the mistake of inaction. Underlying the various threats to human well-being and survival posed by pathogens, environmental destruction, and climate change, are politics and economics, which play a major role in determining our relationship with the living world. We need to seriously rethink this relationship, and to work towards making structural changes in the political landscape in ways that not only reduce the damage we are doing, but also strive to create social justice (Athansiou 1996). Only be tackling this can we create a better, sustainable world for all. 


\section{Acknowledgments}

I wish to dedicate this article to those striving to create a healthier, more equitable and sustainable world. Photograph credits: SARS-Covid-2 molecule courtesy of Alissa Eckert, MSMI, and Dan Higgins, MAMS, and the Center for

Disease Control. Photo of the starving polar bear is by Andreas Weith: https://commons.wikimedia.org/wiki/File:Endangered arctic _starving_polar_bear.jpg; photo of the healthy polar bear is by Zoofari https://www.naturespicsonline.com/galleries/Nature33/_mg_2673.htm

\section{References}

Abate M., Christidis P., Purwanto A.J. (2020), Government support to airlines in the aftermath of the COVID-19 pandemic, "Journal of Air Transport Management", no. 89, 101931.

Ahmed W., Vidal-Alaball J., Downing J., Seguí F.L. (2020), Dangerous messages or satire? Analysing the conspiracy theory linking 5G to COVID-19 through social network analysis, "Journal of Medical Internet Research", vol. 22 no. 5, pp. e19458.

Allington D., Duffy B., Wessely S., Dhavan N., Rubin J. (2020), Health-protective behaviour, social media usage and conspiracy belief during the COVID-19 public health emergency, "Psychological Medicine", no. 9, pp. 1-7.

Amable B. (2011), Morals and politics in the ideology of neo-liberalism, "Socio-Economic Review", no. 9, pp. 3-30.

Aronsson A., Holm F. (2020), Multispecies entanglements in the virosphere. Rethinking the Anthropocene in light of the 2019 coronavirus outbreak, "The Anthropocene Review", https://journals.sagepub.com/doi/full/10.1177/2053019620979326 [17.03.2021].

Athanasiou T. (1998), Divided planet. The ecology of rich and poor, University of Georgia Press, Athens GA.

Bar-On Y.M., Phillips R., Milo R. (2018), The biomass distribution on Earth, "Proceedings of the National Academy of Sciences", no. 115, pp. 6506-6511.

Berthelsen J. (2020), Big pharma's disgusting covid profits, Asia Sentinel, https://www.asiasentinel.com/p/big-pharmas-disgusting-covid-profits [17.03.2021].

Bond P. (2006), Looting Africa. The economics of exploitation, Zed Books, London.

Brook B.W., Sodhi N.S., Bradshaw C.J. (2008), Synergies among extinction drivers under global change, "Trends in Ecology \& Evolution", vol. 23 no. 8, pp. 453-460. 


\section{REFLECTIONS ON THE SARS-COVID-2 PANDEMIC AFTER ONE YEAR ...}

Childs J.E., Mackenzie J.S., Richt J.A. (eds.) (2007), Wildlife and emerging zoonotic diseases. The biology, circumstances and consequences of cross-species transmission, Springer Science \& Business Media, Berlin-Heidelberg.

Chomsky N. (1999), Profit over people. Neoliberalism and global order, Seven Stories Press, New York.

Collins C., Ocampo O., Paslaski S. (2020), Report: Billionaire bonanza 2020. Wealth, windfalls, tumbling taxes, and pandemic profiteers, Institute for Policy Studies, https://ips-dc.org/billionairebonanza-2020/ [17.03.2021].

Cucinotta D., Vanelli M. (2020), WHO declares COVID-19 a pandemic, "Acta Bio Medica: Atenei Parmensis", vol. 91 no. 1, pp. 157-160.

Czech B. (2000), Shoveling fuel for a runaway train. Errant economists, shameful spenders, and a plan to stop them all, University of California Press, Berkeley.

Daszak P., Cunningham A.A., Hyatt A.D. (2001), Anthropogenic environmental change and the emergence of infectious diseases in wildlife, "Acta Tropica", vol. 78 no. 2, pp. 103-116.

de Rugy V., Leff G. (2020), The case against bailing out the airline industry. Special Edition Policy Brief,

https://poseidon01.ssrn.com/delivery.php?ID=312025116122114125099121002074127120117035019

00903409007402511408106708611709607810109603402312101512511411801610107507007808905

90820530650680710730050001190860790250660400761130020750030001100190930290070290850

$73105110065110116006065023127096101005000 \&$ EXT=pdf\&INDEX=TRUE [17.03.2021].

Dirzo R., Young H.S., Galetti M., Ceballos G., Isaac N.J., Collen B. (2014), Defaunation in the Anthropocene, "Science", no. 345, pp. 401-406.

Donnelly S. (2019), The lie of global prosperity. How neoliberals distort data to mask poverty and exploitation, New York University Press, New York.

Duménil G., Levy D. (2002), The nature and contradictions of neoliberalism, "Socialist Register", vol. 38, pp. 43-71.

Ehrenfeld D. (2005), The environmental limits to globalization, "Conservation Biology", vol. 19 no. 2, pp. 318-326.

Foster K.R., Vecchia P., Repacholi M.H. (2000), Science and the precautionary principle, "Science", no. 288, pp. 979-981.

Giroux H.A. (2015), Against the terror of neoliberalism. Politics beyond the age of greed, Routledge, London.

Gough B., Ireland J.L., Jones M.V. et al. (2020), Research priorities for the COVID-19 pandemic and beyond. A call to action for psychological science, "British Journal of Psychology", vol. 111 no. 4, pp. 603-629.

Grewelle R., De Leo G. (2020), Estimating the global infection fatality rate of COVID 19, medRxiv, https://www.medrxiv.org/content/10.1101/2020.05.11.20098780v1 [17.03.2021]. 
Haas C. (2020), Coronavirus and risk analysis, "Risk Analysis", vol. 40 no. 4, pp. 660-661.

Hanlon G., Fleming P.P. (2009), Updating the critical perspective on corporate social responsibility, "Sociology Compass", vol. 3 no. 6, pp. 937-948.

Henig R.M. (2020), Experts warned of a pandemic decades ago. Why weren't we ready?, "National Geographic", no. 8, https://www.nationalgeographic.com/science/article/experts-warned-pandemicdecades-ago-why-not-ready-for-coronavirus [17.03.2021].

Hickel J. (2017), Is global inequality getting better or worse? A critique of the World Bank's convergence narrative, "Third World Quarterly", vol. 38 no. 10, pp. 2208-2222.

Hickel J. (2018), The divide. A brief guide to global inequality and its solutions, Random House, New York.

Hoehl S., Rabenau H., Berger A., Kortenbusch M., Cinatl J., Bojkova D., Behrens P., Böddinghaus B., Götsch U., Hooker L., Palumbo D. (2020), Covid vaccines: will drug companies make bumper profits?, BBC News online, 18 December 2020, https://www.bbc.com/news/business-55170756 [17.03.2021].

Jones D.S. (2014), Masters of the universe. Hayek, Friedman, and the birth of neoliberal politics. Updated edition, Princeton University Press, Princeton NJ.

Kelly J. (2020), Billionaires are getting richer during the Covid-19 pandemic while most Americans suffer, Forbes. Com, April 27, https://www.forbes.com/sites/jackkelly/2020/04/27/billionaires-aregetting-richer-during-the-covid-19-pandemic-while-most-americans-suffer/ [17.03.2021].

Kerr R.A. (2004), Three degrees of consensus. Climate researchers are finally homing in on just how bad greenhouse warming could get - and it seems increasingly unlikely that we will escape with a mild warming, "Science", no. 305, pp. 932-945.

Kim Y.C., Dema B., Reyes-Sandoval A. (2020), COVID-19 vaccines. Breaking record times to first-inhuman trials, "Npj Vaccines", vol. 5 no. 34, pp. 1-3.

Kotz D.M. (2015), The rise and fall of neoliberal capitalism, Harvard University Press, Cambridge MA.

Kriebel D., Tickner J., Epstein P., Lemons J., Levins R., Loechler E.L., Quinn M., Rudel R., Schettler T., Stoto M. (2001), The precautionary principle in environmental science, "Environmental Health Perspectives", vol. 109 no. 9, pp. 871-876.

L'Etang J. (1994), Public relations and corporate social responsibility. Some issues arising, "Journal of Business Ethics", vol. 13, pp. 111-123.

Leung C.C., Cheng K.K., Lam T.H., Migliori G.B. (2020), Mask wearing to complement social distancing and save lives during COVID-19, "International Journal of Tuberculosis and Lung Diseases", vol. 24, pp. 556-558.

Lopes L.R., de Mattos Cardillo G., Paiva P.B. (2020), Molecular evolution and phylogenetic analysis of SARS-CoV-2 and hosts ACE2 protein suggest Malayan pangolin as intermediary host, "Brazilian Journal of Microbiology”, vol. 51, pp. 1593-1599. 


\section{REFLECTIONS ON THE SARS-COVID-2 PANDEMIC AFTER ONE YEAR ...}

McGuigan J. (2014), The neoliberal self, “Culture Unbound”, vol. 6 no. 1, pp. 223-240.

Monbiot G. (2016), Neoliberalism - the ideology at the root of all our problems, "The Guardian", https://www.theguardian.com/books/2016/apr/15/neoliberalism-ideology-problem-george-monbiot [17.03.2021].

Naujoks F., Neumann P. (2020), Evidence of SARS-CoV-2 infection in returning travellers from Wuhan, China, "New England Journal of Medicine", no. 382, pp. 1278-1280.

O’Connor D.B., Aggleton J.P., Chakrabarti B., Cooper C.L., Creswell C., Dunsmuir S., Fiske S.T., Gathercole S., Peters M.A. (2012), Neoliberalism, education and the crisis of Western capitalism, "Policy Futures in Education", vol. 10 no. 2, pp. 134-141.

Platje J., Harvey J., Rayman-Bacchus L. (2020), COVID-19 - reflections on the surprise of both an expected and unexpected event, "The Central European Review of Economics and Management", vol. 4 no. 1 , pp. 149-162.

Plowright R.K., Eby P., Hudson P.J., Smith I.L., Westcott D., Bryden W.L., Middleton D., Reid P.A., McFarlane R.A., Martin G., Tabor G.M. (2015), Ecological dynamics of emerging bat virus spillover, "Proceedings of the Royal Society B: Biological Sciences", vol. 282 no. 1798, https://royalsocietypublishing.org/doi/full/10.1098/rspb.2014.2124 [17.03.2021].

Rogelj J., Den Elzen M., Höhne N., Fransen T., Fekete H., Winkler H., Schaeffer R., Sha F., Riahi, K., Meinshausen M. (2016), Paris Agreement climate proposals need a boost to keep warming well below 2 C, "Nature", no. 534, pp. 631-639.

Quammen D. (2012), Spillover: animal infections and the next human pandemic, WW Norton \& Company, New York.

Rich N. (2019), Losing Earth. The decade we could have stopped climate change, Palgrave Macmillan, New York.

Sandin P., Peterson M., Hansson S.O., Rudén C., Juthe A. (2002), Five charges against the precautionary principle, "Journal of Risk Research", vol. 5 no. 4, pp. 287-299.

Sternfeld J. (2020), Unprepared. America in the time of coronavirus, Bloomsbury Publishing, New York.

Thompson A.E. (2009), Commentary. Those who do not learn from history are doomed to repeat it, "Academic Medicine", vol. 84 no. 2, pp. 157-158.

Vlachopoulos D. (2020), COVID-19: threat or opportunity for online education?, "Higher Learning Research Communications", vol. 10 no. 1.

Volpert V., Banerjee M., d'Onofrio A., Lipniacki T., Petrovskii S., Tran V.C. (2020), Coronavirus scientific insights and societal aspects, "Mathematical Modeling of Natural Phenomena", vol. 15, https://www.researchgate.net/publication/340415317_Coronavirus_-

_Scientific_insights_and_societal_aspects [17.03.2021]. 


\section{Jeffrey A. HARVEY}

Walker K.L.M. (2008), Neoliberalism on the ground in rural India. Predatory growth, agrarian crisis, internal colonization, and the intensification of class struggle, "The Journal of Peasant Studies", vol. 35 no. 4, pp. 557-620.

Wimalawansa S.J. (2020), Global epidemic of coronavirus - Covid-19. What can we do to minimize risks, "European Journal of Biomedical Pharmacy and Science", vol. 7 no. 3, pp. 432-438.

Xu X.W., Wu X.X., Jiang X.G., Xu K.J., Ying L.J., Ma C.L., Li S.B., Wang H.Y., Zhang S., Gao H.N., Sheng J.F. (2020), Clinical findings in a group of patients infected with the 2019 novel coronavirus (SARS-Cov-2) outside of Wuhan, China: retrospective case series, "Bmj", no. 368, https://www.bmj.com/content/368/bmj.m606 [17.03.2021].

Ye Z.W., Yuan S., Yuen K.S., Fung S.Y., Chan C.P., Jin D.Y. (2020), Zoonotic origins of human coronaviruses, "International Journal of Biological Sciences", vol. 16 no. 10, pp. 1686-1697.

Zhang T., Wu Q., Zhang Z. (2020), Probable pangolin origin of SARS-CoV-2 associated with the COVID-19 outbreak, "Current Biology", vol. 30 no. 8, pp. 1346-1351.

Zhou P., Yang X.L., Wang X.G., Hu B., Zhang L., Zhang W., Si H.R., Zhu Y., Li B., Huang C.L., Chen H.D. (2020), A pneumonia outbreak associated with a new coronavirus of probable bat origin, "Nature", no. 579, pp. 270-273. 


\section{Harvey - Figure legend}

Hypothetical timeline depicting societal responses to an immediate calamity (i.e. SARS-Covid-2, represented by a molecule of the virus) and a slowly emerging but more serious threat (i.e. climate change, represented by a healthy or starving polar bear) under political and economic systems that are based on either (A) short-term profit maximization and economic growth (e.g. neoliberalism) or (B), a more egalitarian system (e.g. steady-state economics) that considers longer-term impacts of human activity. Blue shading depicts high preparedness to immediate and emerging threats, whereas red shading depicts a lack of preparedness to threats irrespective of the time-scale involved. The impact of the threat is hypothetically proportional to the size of the subjects depicted. By applying the precautionary principle, threats posed by novel pathogens and climate change are reduced or eliminated, whereas under the neoliberal model the precautionary principle is downplayed or ignored. When this happens, pandemics are more likely to occur and society only responds after the fact through the rapid development of vaccines, but with enormous societal and economic costs. Given that governments have procrastinated on measures to address climate change, the future prognosis under neoliberalism is dire. 

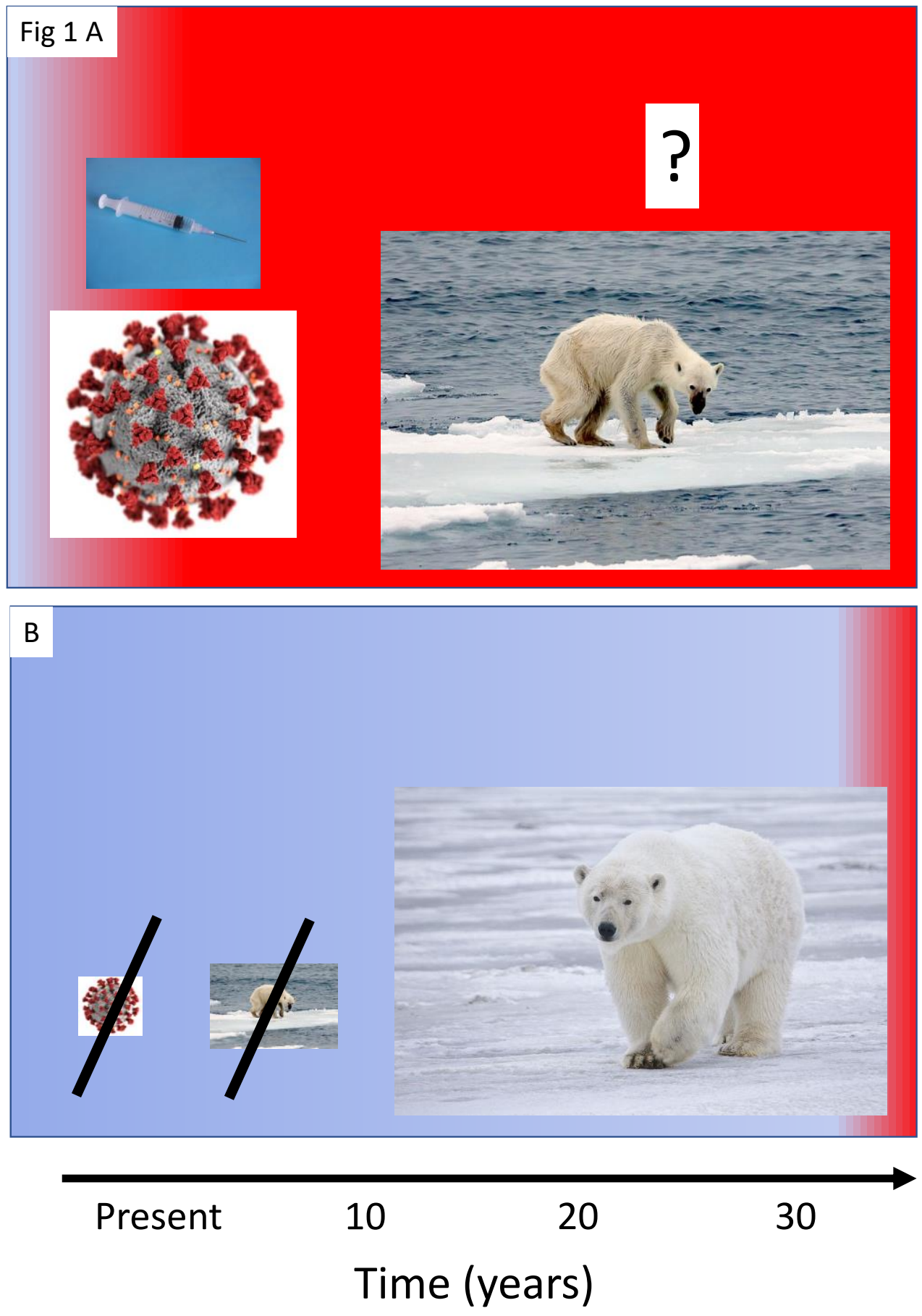